\title{
Politics, science, and the world of digital networks
}

If Max Weber could analyze the first two decades of the twenty-first century, he would be intellectually instigated by the degree of irrationalism of contemporary "politics." If this 'version' of the German author was the one associated with romanticism and cultural pessimism, Weber would be sure that his metaphor of the 'iron cage' had been confirmed in its most radical form. Bureaucratic rationality - which, in the author's conception, would represent one of the singularities of capitalism in comparison with other systems - seems to share space, without contradictions, with irrationality. Rationality, a modern form of domination, produced the reification of social relations and the disenchantment of the world. In this sense, Weber would agree with Marx that modern capitalism is a universe in which individuals are driven by abstractions, "in which impersonal and reified relationships replace personal dependency relationships and in which capital accumulation becomes an end in itself, largely irrational"(Löwy, 2014, p. 18, our translation).

Habermas (1980) reminds us that Weber introduced the concept of "rationality" to determine the form of economic activity in capitalism, of bourgeois private law relations, and the form of bureaucratic domination. The progressive rationalization of society, for the author, is connected to secularization and the institutionalization of scientific and technical progress. As far as technique and science penetrate the structures of society, the old ways of legitimizing traditional institutions collapse. Therefore, different from Parsons' structural and functionalist interpretation of Weber's work, Habermas - influenced by Lukács - impacted the tradition of the critical theory, particularly the notion of instrumental reason.

What do we see today if not the exacerbation of that instrumental reason, i.e., the use of science and technique as a form of production and reproduction of the capital order? How can we not find a profound abstraction of social relations in the disseminated information and communication technologies, which further intensify what Marx called commodity fetishism? Every day, more and more machines are self-governing and communicating with each other - as is the case of the "Internet of Things" - increasing pessimism about an emancipatory exit.

If revolutionary utopias seem to have been temporarily defeated after the end of post-capitalist societies in the late 1980s, reactionary utopias gained incalculable projections, associated with religious thought, and disseminated by information-digital media. As Lukács observes, reactionary utopias that aim to restore a past condition cannot fail to have an irrationalist character. This worldview can only overcome antinomies founded on a negation of the ratio in a pseudo-dialectic and sophistic way (Lukács, 2012).

Humanity has long since ceased to find refuge in the Enlightenment project that rose from the bourgeois society. The decay and degeneration of capitalism overcame the project's progressive nature, as the critical theory analyses corroborate. When reflecting on Marcuse's conception of the unacknowledged political domination of instrumental reason, Habermas stresses that it

extends to the correct choice among strategies, the appropriate application of technologies, and the efficient establishment of systems (with presupposed aims in given situations), it removes the total social framework

\section{(ब) $\odot \otimes$}

(C) The Author(s). 2020 Open Access This article is distributed under the terms of the Creative Commons Attribution-NonCommercial 4.0 International License (http://creativecommons.org/licenses/by-nc/4.0/), which permits use, distribution, and reproduction in any medium, since it's for non-commercial purposes, and provided you give appropriate credit to the original author(s) and the source, provide a link to the Creative Commons license, and indicate if changes were made. 
of interests in which strategies are chosen, technologies applied, and systems established, from the scope of reflection and rational reconstructions (Habermas, 1980, p. 311).

What is surprising in contemporary society - and this is an exciting challenge for the social sciences - is that this irrationality has proliferated and gained dimensions (until now incalculable) with the diffusion of new information and communication technologies and with the most modern automated machinery implemented in the productive world. Before the Covid-19 pandemic, some authors and business personalities announced that the ongoing technological revolution would lead us to a brave new world in which technical progress would bring about the emancipation of the most arduous tasks in the spheres of production and social reproduction (Schwab, 2017). Nothing more fallacious than this old bourgeois promise. The health crisis itself - which has social, political, and economic dimensions - exposed the most latent contradictions of capital.

Digital platforms are a direct result of these technological transformations, and have become powerful instruments of economic, social, and political relations. After a few decades of fierce disputes among various companies and "innovative entrepreneurs," the sector became restricted to few companies. The two most important are the Facebook and Google. The first is the largest social media in the world, reaching 2.3 billion people, and controls not only the application of the same name but also the other three main social media applications (FB Messenger, Whatsapp, and Instagram). The second company is the most important search engine used on the planet (with the exception of China) and owns an operating system (Android), Youtube, and Gmail. Thus, it is possible to say that:

digital platforms are technological systems that function as active mediators of interactions, communications, and transactions between individuals and organizations. that operate on a connected digital technological base (especially on the Internet), providing services based on these connections, strongly backed by data collection and processing, and marked by network effects (Valente, 2019, p. 170, our translation).

This issue of Revista Katálysis proposes a reflection on the relations between Politics, Science, and the World of Digital Networks. It gathers articles from the field of social work and related areas on the role of using information, working with data, using electronic systems, and digital networks in professional intervention and knowledge production. It also questions the new formats and possibilities for democratic participation, control, and access to public information, understanding social media both as an instrument of reification and domination, and as potentials for connection and organization of social movements.

The dossier contains articles resulting from theoretical and empirical research. In the first case, the article entitled Lukács: the "socially needed false" shows the importance of Lukács' concept of "socially necessary false" to the research on the current political force of ideas and conceptions "fantastically untrue." Hermeto, inspired by Lukács and Hegel, presents in the article Towards a criticism on intellectual property, an immanent criticism of the category of intellectual property, from the perspective of labor and the cultural development of human thinking. The author aims to understand the essence and outcomes of digital and online worldwide relationships.

Three articles discuss the topics of politics, biopolitics, hate speech, and neoliberalism. Veiga Dias and Amaral, in Data control and management of the post-democratic life, understand technology as part of the relations of bio-political control and, in this sense, examine how the current neoliberal control project affects Brazilian society as a recent democracy. Oliveira and Cerrat, in their article Poverty as malware: social rights applications and setbacks, point out the relationship between applications and the economic crisis of 2008 and the setbacks in social protection systems under the influence of neoliberal rationality. Finally, Hate and intolerance in social media by Quadrado and Ferreira, analyzes hate speech and intolerance in social media and complements the discussion of this group of articles. These three articles seek to understand how much these technologies and policies threaten the Brazilian liberal democracy.

Another group of works published in this issue of Katalysis addresses the debate on gender, feminism, and the digital world. Oliveira, Silva, and Silveira, in their work Women, feminism, and ICTs, problematize the use of the Internet by oppressed and socially marginalized groups, in particular the feminist movement. In the article Feminists struggles and coordination through social media: critical perceptions, Castro emphasizes social media as an instrument for feminist struggles, pointing out that they expand both the scope of their speeches and the intensity of the opposite reactions. Silva and Souza, in Social media and motherhood activism: challenges of students from a public university, present the findings of empirical research on the conditions of the permanence of students who are mothers at a federal public university. Finally, Ramires, analyzes the discourse of female Brazilian sports journalists who came together to denounce situations of harassment and violence suffered at work in the article Female sports journalists and labor Market: who lets (or does not let) them work? 
Another four articles complete this issue. Orth and Soares in Brazilian Communication Corporation $(E B C)$ : the decay of public communication, analyze the dismantling process of the public company. In the article, The influence of people's participation through digital platforms in the proposition state-level bills, Ladinho Junior and Dufloth present the results of research on the "e-participation" channels on the Internet portals of the Legislative Assembly of the Brazilian state of Minas Gerais, the Chamber of Deputies, and the Brazilian Senate. The authors sought to understand how much ordinary citizens influence the proposition of bills by sending suggestions through these digital platforms. Schuartz and Sarmento analyze the impacts of information and communication technology on education. Finally, Raposo, in Digital slavery and labor super-exploitation: consequences for the working class, addresses the issue of job insecurity and digital platforms, with special emphasis on the service sector, particularly on the work monitored and controlled by new technological and online devices.

This issue of Revista Katalysis successfully points out and problematizes some pressing issues in contemporary society, linking the relationship between politics, science, and the world of digital networks. We encourage everyone to read and discuss these articles ${ }^{1}$.

Ricardo Colturato Festi, Brasilia, June 30, 2020.

\section{References}

HABERMAS, J. Técnica e ciência enquanto "ideologia": para os 70 anos de Hebert Marcuse, no dia 19-VII-1968. In: BENJAMIN, W.; ADORNO, T. W.; HOKHEIMER, M. (Eds.). Textos escolhidos. São Paulo: Abril, 1980. p. 343.

LÖWY, M. A jaula de aço: Max Weber e o marxismo weberiano. Tradução: Mariana Echalar. São Paulo: Boitempo, 2014.

LUKÁCS, G. Para uma ontologia do ser social I. Tradução: Carlos Nelson Coutinho; Tradução: Mario Duayer; Tradução: Nélio Schneider. São Paulo: Boitempo, 2012.

SCHWAB, K. La quatrième révolution industrielle. Malakoff: Dunod, 2017.

VALENTE, J. Tecnologia, informação e poder: das plataformas digitais online aos monopólios digitais. Tese de Doutorado-Brasília, D.F.: Universidade de Brasília, 2019.

\section{Nota}

1 Editor's note: This issue of Katálysis features articles in an area entitled "espaço tema livre" (area of articles addressing general topics) and in an area "espaço especial" (special area). The special area features articles written by speakers who presented studies in two important scientific events that took place in 2019: III National Seminar on Social Work, Labor and Social Policy (UFSC), and the National Seminar on Work in Contemporary Society (UFAL).

\section{Ricardo Colturato Festi}

https://orcid.org/0000-0001-6360-2875

ricardo.festi@unb.br

$\mathrm{PhD}$ in sociology from the University of Campinas (UNICAMP)

Adjunct Professor in the Department of Sociology at the University of Brasília (UnB)

\section{UnB}

Instituto de Ciências Sociais

Campus Darcy Ribeiro

Asa Norte

70910900 - Brasília, DF - Brazil 